\title{
Development of E-learning System Using Felder and Silverman's Index of Learning Styles Model
}

\author{
Supangat $^{1}$, MohZainuri Bin Saringat ${ }^{2}$ \\ ${ }^{1}$ Information EngineeringDepartment, Indonesia, supangat@untag-sby.ac.id \\ ${ }^{2}$ Information, Computer And Communications Technology, Malaysia, zainuri@uthm.edu.my
}

\begin{abstract}
The existing online education system mostly provides users with undistinguished learning content. The existing online education system assumes that users have the same characteristics or tendencies as one another. Every user is not the same; they have different characteristics, tendencies, and learning preferences. Each user has different personal characteristics, but today's online education systems ignore them. This study use Felder Silverman's learning style model. Through characteristic learning styles,relationships, and content types result in more personalized e-learning. Researchers distributed questionnaires to Informatics Engineering students at, University of August 17, Surabaya, and managed to get 277 student respondents. This data uses to determine student learning styles using a questionnaire-based psychometric instrument called the index of learning style (ILS), which uses to determine learning styles. The questionnaire, validity, reliability, determination of learning styles, learning content, and material requirements are testing. This study concludes that the questionnaire used meets the standards for determining learning styles for users. The system that builds has five modules to facilitate construction. These modules include the media library, domain repository, student model, instruction model, adaptive engine, and user interface. It can conclude that the modules made can help lecturers to distribute material according to the material content that is suitable for student learning styles and helps students to study more effectively according to their preferences.
\end{abstract}

Key words: E-learning System, Distance Education, Index of Learning Style

\section{INTRODUCTION}

In modern times today, the application of learning methods has collaborated with technology as a supporting medium for the smooth learning process (i.e., Zoom, Skype, Teams, Whatsapp) [1]. By utilizing advances in electronic technology and advances in internet technology, electronic learning (e-learning) has been created, or it can be called online learning. This advanced technology has been sucessfully applied for distance education since 2003 [2].

In 2019, COVID '19 outbreak was wide spread around the world. 38,085,762 infected patients has been detected which $28,628,813(96 \%)$ has been recovered and 1,086,055 deaths (4\%) In ten months [3]. Even the transfer rate is rapid and affected the whole world in very short period, the dead rate is quite low. In spite of that fact, almost all country has been implementing preventive policy such as social distancing and stay at home to response COVID '19 Pandemic. Under this partial lockdown, public activities has been closed (i.e., education, economic and tourism), and enforce people doing activities at home such as work from home [4] or distance education [5]. Almost 1,5 billion student in 165 country cannot attend to their classroom due to COVID 19 Pandemic lockdown [6]. Under this pandemic, learning-teaching activities have been shifting from school to private home using mobile phone communication and application (i.e. Zoom allow up to 100 people at a time) [7]. More than 90.000 education institution around the world used Zoom to perform teaching-learning and Zoom application is becoming more popular among student and teacher to hold video conference and webinar even privacy risk is appear [8]. So that, e-learning is becoming more important to keep learning process running well.

E-learning that exists today generally does not provide a limit for users, or it can be said that there is no classification for its users. So, it can be said that e-learning currently only provides learning material that can be accessed online without providing special restriction for users who have specific characteristics. The fact is that each user has different abilities in processing information. Furthermore, educational institution waste massive data of e-learning which is not meet individual demand and goal [9]. Therefore, it can be concluded that e-learning that has not provided user restrictions is still not effective in obtaining information by its users and wasted in educational institution data server.

Ideally, e-learning provides features according to user characteristics to comfortably use the media [10]. E-learning should adapt its appearance to variations in its users' 
characteristics or be able to personalize individual learning styles [15]. This e-learning system must provide teaching materials that are appropriate and suitable for the user's interest. It means that the e-learning system is required to be adaptive by the differentiation of user characteristics.

In a survey at public high school in Yogyakarta, Indonesia, 2015. Regarding student learning outcomes, it found that some students had scores below the minimum completeness criteria (KKM) by $65 \%$, while those who achieved it were $45 \%$. So that the survey conducted further research on teacher teaching style, learning styles, and media. The next results in the student questionnaire analysis found that the way the teacher taught still used conventional methods not to match students' characteristics (learning styles) [17].E-learning failure is reporting appear when the instruction cannot match with the student expectation [18]. Despite the online environment having a strong relationship with learning behavior [8], teaching style adaptation with each student's learning styles will enhance distance education [19]. The learning style can be used by a teacher to convey material content for students [11].Learning style is considering a valid predictor of success in a Web-based learningenvironment[19]. So, it can say that a student's learning style cannot be ignored and is very influential in determining the success of processing and obtaining student information in e-learning.

Learning style refers to aindividual preference in acquiring information, skills, attitudes or knowledgethrough experience or study while it can differ in favor one spesific teaching style over another [20]. The high quality of the e-learning system is e-learning adapted to individual learning styles; this e-learning system is called adaptive e-learning. Adaptive e-learning is an e-learning system that adapts the presentation of information and the overall relationship structure for users according to learning styles [16]. Adaptive e-learning can design with various learning styles models. The need for adaptive e-learning media about individual learning styles is visual, auditory, and kinesthetic [13]. Because basically, individual learners use these three sensory in the information processing process, either one or two are dominant.

Learning style models are developing over time. There are currently several different learning styles from the learning styles with the VAK concept (Visual, Auditory, and Kinesthetic). One of the VAK concepts is Felder and Silverman's learning style model [21]. Felder and Silverman's learning model's design suggest that teaching style should focus on four dimensions of learning style (sensory/intuitive, inductive/deductive, active/reflective, sequential/globally) and sensory channel (visual/auditory) [21]. Individual learning styles can determine by analyzing the individual inclination to which of the four dimensions [14].A recent study prefers to use Honey and Mumford's learning style model rather than Felder and Silverman's learning style model because Honey and Mumford's learning style model focuses on perceiving and processing information [23]. This study prefers to Felder and Silverman's learning style model because it focuses on perceiveing, arranging, processing and understanding information. This learning style identification will support teaching style adaptation more comprehensively. In this study, the index of learning style (ILS) is using to measure student tendency to each dimension.

So that from the description of the existing problems, adaptive e-learning was designed with the Felder and Silverman model that can personalize individual learning styles. By obtaining user information, namely information on determining learning styles, material content, and teaching material needs, it is hoped this adaptive e-learning is designing to be a solution for successful distance education at home.

\section{LITERATURE REVIEW}

\subsection{Index of Learning Style (ILS)}

Determining Felder Silverman's learning style using an assessment instrument psychometric-based questionnaire called an index of learning style (ILS). ILS is a summary questions from the four dimensions of the Felder Silverman'learning style model consisting of 44 questions and has a vulnerable value of

+11 to -11 for each dimension. Any questions have two answer choices that will determine one of these learning styles' strengths/tendencies. The results of the answers from the ILS will be accommodating in the ILS. The scoring sheet is then positioned with put the ILS Report form.

The ILS value can divide into three susceptible scales with values. 1-3 means that the learning style is balanced (balanced) in a learning style dimension. A value of 5-7 means that students are comfortable with one learning style on a dimension, and a value of 9-11 means that students can only study with a learning style on one learning dimension. Results of the ILS Scoring sheet can be mapped to the ILS Report form to see that students have Active, Intuitive, Visual, and learning style preferences Sequential (figure 1). students also still adapt to the learning style on the dimensions Visual / Verbal and Sequential / Global due have a balanced value.

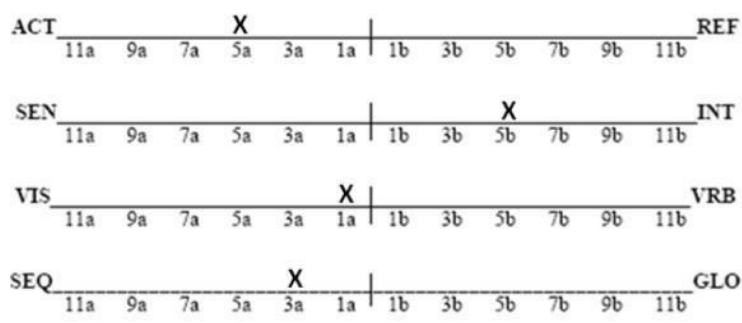

Figure1: Index of Learning Style (ILS) Scoring Form

\subsection{Felder-Silverman's Learning Style}

This learning style model is often used in refined learning technology and designed for traditional learning. It consists of 
four dimensions, based on a tendency that indicates individuals with high preferences for specific behaviors, which can sometimes act differently. The Felder-Silverman learning style model divides learning styles based on four dimensions. These learning styles consist of active-reflective learning styles, visual-verbal learning styles, sensingintuitive learning styles, and sequential-global learning styles.

1. Active-Reflective Learning Style (Processing Dimension)

Active learners learn more by looking at things and not sitting with textbooks and reading what they need to do. Active learners find it easier to discuss what something means to people by providing examples and explaining to others what needs to do. Active learners like to work in groups and not individually. Sitting in halls where they have lessons are taught tends to be more boring for active prefer to work in a group to get all member's thoughts out, then they share personal points of view to discuss best idea.

Reflective learners process information by receiving, listening and deep thinking. Unlike active learners, reflective learners prefer to learning situation with opportunity to think information being presented without any distractions. Reflective learners sometimes take notes in lessons. Reflective learners help themselves in the future by reading the notes and memorizing information, then frequently stop to think what they have learned.

2. Sensing-Intuitive Learning Style (Perception Dimension)

Sensing learners are those who enjoy working on the scope of facts and figures for a topic. Because these learners work best with numbers, Sensing learners like to recap the material they have studied previously. This type of learner does not like courses that have nothing to do with what they are learning. This type of student is also the more patient who will see the work to the end without getting bored.

Intuitive learners like to work with principles and theories. Intuitive learners do not like repetition. Intuitive learners can help themselves in the future by asking facts that will relate to the course they are studying.

3. Visual-Verbal Learning Style (Input Dimension)

Visual learners prefer to perceive information by seeing some object to see the whole concept of the information to understand. teachers can use some flow charts,drawings (diagrams), timelines and moving object such as demonstrations, experiment or films. Visual learners tend not to read word; they prefer to learn the lessons are demonstrated by teacher (photo, diagram, film). Visual learners help themselves in the future by findingfilm, diagrams such as pictures, photos, and flowcharts to memorize information and present concept visually.

Verbal learners perceive information by hearing to words, which means they can better interpret the whole concept with specific word. It does not matter if the information are presented verbally or spoken. Verbal learners access information through formal written text or informal speech.

4. Sequential-Global Learning Style (Dimension of Understanding)

Sequential learners tend to learn to follow instructions; this makes it easier for them to understand. Sequential learners tend to put things together easily and quickly and get the big picture almost instantaneously.

Global learners learn little steps that leap. Taking their time to understand a concept about something is what global learners usually do, but after a while, they will immediately understand what they want to do. It means that they do not always see the relationship between logical steps. Global learners can help themselves in the future by looking at the bigger picture. Looking at the entire unit plan to understand what they will study will help global learners.

Table 1. Information about Learning Style

\begin{tabular}{|c|c|c|}
\hline Dimension & Learning Style & Information \\
\hline Processing & Active & \multirow{2}{*}{$\begin{array}{l}\text { How students process } \\
\text { information? }\end{array}$} \\
\hline Dimension & Reflective & \\
\hline Perception & Sensing & \multirow{2}{*}{$\begin{array}{l}\text { How dostudents perceive } \\
\text { information? }\end{array}$} \\
\hline Dimension & Intuitive & \\
\hline Input & Visual & \multirow{2}{*}{$\begin{array}{l}\text { What kind of information } \\
\text { which is easy to accept? }\end{array}$} \\
\hline Dime & Verbal & \\
\hline Understanding & Sequential & How about a studentcan \\
\hline Dim & Global & \\
\hline
\end{tabular}

\section{RESEARCH SCOPE AND METHODOLOGY}

E-learning design requires several stages so that it can be said to be adaptive. Conventional e-learning, or what can be called Web-Based instruction, is e-learning that generally exists today, which still does not focus on personalizing individual learning styles. This e-learning displays the same information to all individuals regardless of differences in user characteristics. Besides, conventional e-learning is only oriented towards certain target users so that users with other classifications cannot receive it optimally.

In this research, it attempts to overcome the shortcomings of conventional e-learning. The design is not oriented towards a user but will adjust to the user's characteristics. The Felder Silverman learning style model will maximize the determination of the type of learning style where the Felder-Silverman learning style model divides learning styles based on four dimensions. These learning styles consist of active-reflective learning styles, visual-verbal learning styles, sensing- intuitive learning styles, and sequential-global learning styles.

The process of determining learning styles will be grouping into eight styles: active, reflective, sensing, intuitive, visual, 
verbal, sequential, and global. The user's learning style will then determine the supporting content displayed to the user, whether concerning web content, multimedia, books, and mind maps.

The results of determining this learning style will help to teach lecturers in managing the material. The material will be grouping according to the user's learning style. User learning styles will store in a student model, which will contain information on learning styles and learning history.

The research method used in this research is a system development method consisting of needs analysis, data collection, application design, implementation, testing and repair, and documentation.

\subsection{System Architecture}

This adaptive online module system has a central architecture consisting of a media library, domain repository, student model, instruction model, adaptive engine, and user interface, as shown in Figure2.

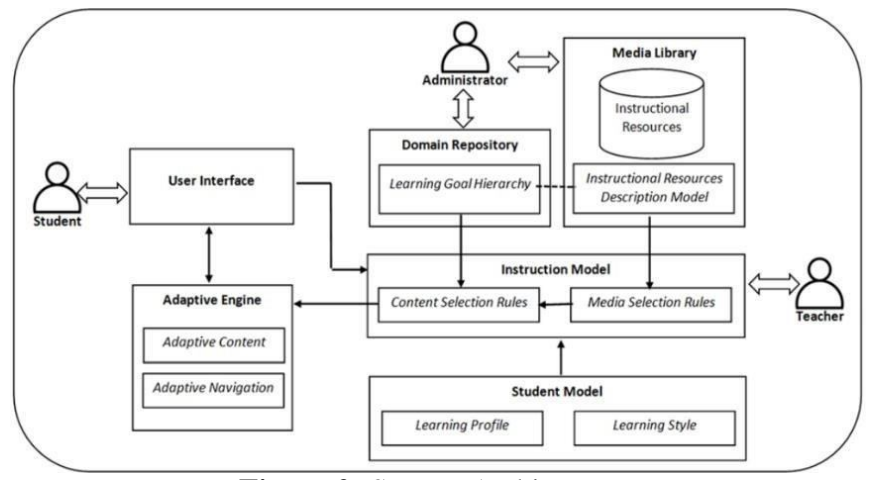

Figure 2: System Architecture

a. Media Library

The media library's primary function is to store all types of instructional resources in an instructional resource database. The database stores all learning materials, such as text, images, audio, video, animation, etcetera.

b. Repository Domain

The domain repository is a repository for storing and organizing instructional content in a specific area, such as courses. The repository domain consists of a hierarchy of learning objectives. Based on the hierarchy of learning objectives and instructional resources, the knowledge domain was composed of knowledge components and their relationships. All components of knowledge are storing in an instructional resource database.

c. Student Model

Student models are an essential part of adaptive online module system. They are used to provide principles for idetifying the learning process and developing adaptive learning support. Based on system demand, the student model stores learner information such as learning styles and learning history. This adaptive online module system builds a student model by filling a questionnairehen students $\log$ in for the first time before learning.

d. InstructionModel

Instruction model is used to develop teacher's teaching strategy, which is storing in special teaching rules, whose primary function focus on selecting teaching lesson content and learning media based on specific learning materials to develop adaptive learning content for learners. The process that occurs in the instruction model is as follows: Determining the learning material, the instruction model determining the teaching content through the domain repository, then determining the specific teaching lesson content, the instruction model selecting teaching media in the media library based on the learning style in the student model. After that, the instruction model will send adaptive learning content to the adaptive engine.

\section{e. AdaptiveEngine}

Adaptive engine stores the system rules, includeadaptive content and navigation support rules. Adaptive content rules solve adaptability problem of content presentation. Fordifferentusers,thesystem willpresentinformationaccordingtotheusersothatusers can process and understand it. Adaptive navigation support rules solve adaptability issues at the link level, which will guide the user to the relevant information. Standard technologies of adaptive content presentation include stretch text,conditional text, page variables, etcetera. Popular technologies of adaptive navigation include adaptive link sorting,live guidance,adaptive link generation, adaptive link, adaptive link hiding, annotation, map adaptation, etcetera. The adaptive model serves and delivers adaptive learning content to the user interface based on adaptive presentation rules and adaptive navigation rules.

\section{f. UserInterface}

The user interface or user interface provides the interaction function between the learner and the adaptive online module system. The user interface varies between everyone. Learners learn adaptive content and send requests to the system. The adaptive online module system receives feedback from learners.

\subsection{System Design}

The author compiles a use case diagram to illustrate how the application will work. The previous stage has obtained information in the form of users involved and the application's standard workflow. The most straightforward use case diagram represents user interactions with the system showing the relationship between users and the various use cases in which the user is involved.

Use case Diagram describes the interactions between actors initiators of the interaction of the system itself with existing systems. Use cases are representing in a simple sequence of steps. Figure 3 is the result of the author's analysis into the Use 
case Diagram.

From the Use Case Diagram image below is the result of an analysis of Information gathering. There are three actors involved in the picture, including lecturers, students, and admin. The following is an explanation of the processes that occur in the Use Case Diagram below:

1. Filling out the questionnaire, here is the process where students are required to fill out a questionnaire totaling 44 questions. There, this questionnaire is using to determine student learning styles.

2. Enter Learning Class is a student entering a class where they are registering in the class. The student must be registered to enter the class; the admin is tasking with entering the class.

3. Following the lesson is a student activity where he uses the system's learning features, including accessing the material.

4. Doing assignments is an activity where students work on assignments that have been given by the lecturer.

5. Accessing learning material is an activity of students and lecturers where they access the lecturer's material. The material received by students may differ from one another, depending on the student's learning style.

6. Student attendance is a lecturer activity to fill in the attendance list or participate in learning activities in that class.

7. To accessthemedialibrary. Themedialibraryisaplacetostorealltypesofinstructionalres ourcesinaninstructionalresourcedatabase. Thedatabasesto resalllearningmaterials, such as text, images, audio, video, animation,

etcetera.

8. The admin is responsible for managing classes such as creating, editing, and deleting classes. Here the admin is also in charge of entering students into indidalclasses.

9. Managingusers,adminscreatestudentandlectureraccounts .Editinganddeleting,fillinginstudent and lecturerprofiles

10. Questionnaire management: The admin oversees the questionnaire that the student will fill in the first time he enters thesystem.

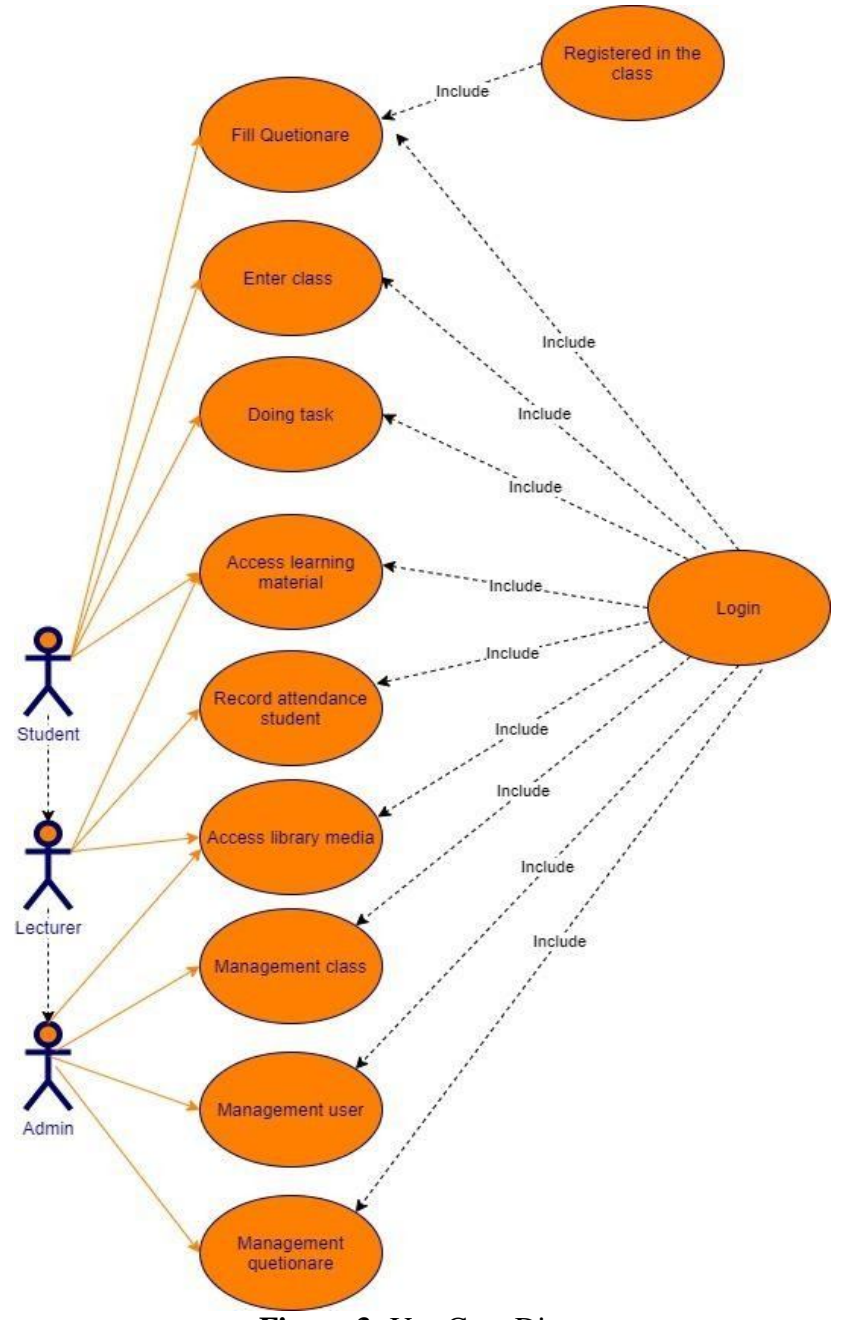

Figure 3: Use Case Diagram

\section{RESULT AND DISCUSSION}

After conducting research and system development with the previous method, the results and full discussion explain in the following sub-chapters.

\subsection{Determinants of Learning Styles}

One of the essential things in adaptive e-learning that the author has developed is the determination of learning styles. The validity and reliability tests ensure that the questionnaire's results produced the correct learning style output. Students' learning styles would be very influential in using this e-learning.

A questionnaire-based psychometric assessment instrument called the index of learning style (ILS) is using in determining learning styles. The ILS method uses the tendency of the answers chosen by the user in determining their learning style. The ILS scoring sheet can see in Figure 4 below. 
Table 2. Scoring Sheet ILS

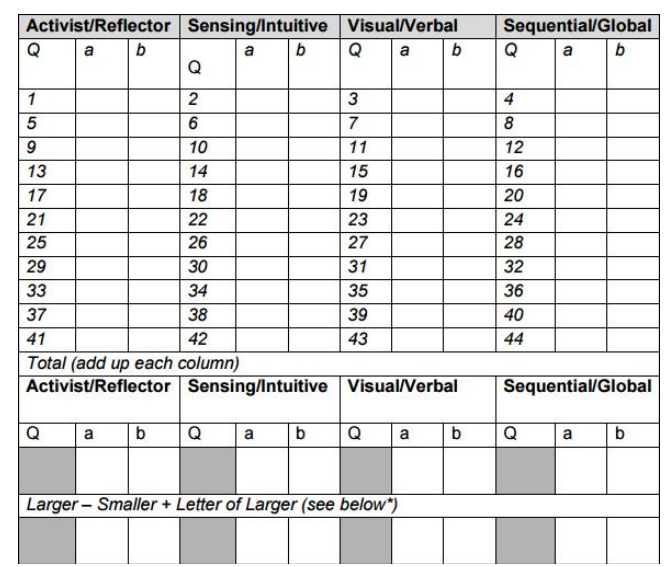

To determine student learning styles, students must fill out a questionnaire on the questionnaire menu. Forty-four questionnaires must fill in. After filling in all the questions, by clicking submit, the system will determine what learning styles the students have, as shown in Appendix I and Figures 4

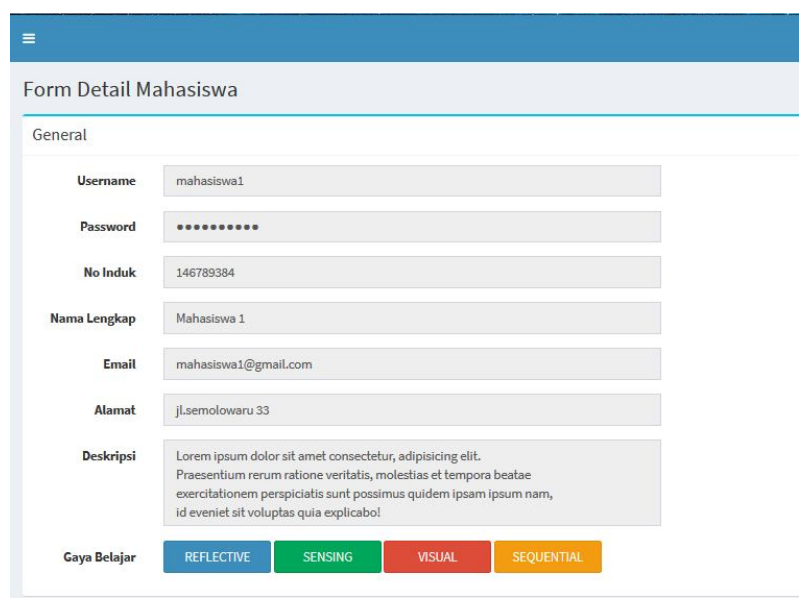

Figure 4: Student Detail Page

\subsection{Learning Content}

Supporting learning resources are additional learning resources provided to students as an extension of their learning material. Material studies have become more dynamic. In adaptive e-learning that the author builds, learning content is the main subject that arranges into adaptive according to each student's learning style preferences. In Bernard and Jason and friend, research explains that the source of learning support content divides into 4.

a. Reference Web

Is a supporting learning resource in the form of a link or text link to a web page in the same context as students' material? Web refs are using for learning styles that have text predominantly, and as detailed information, what is appropriate is active, sensitive, verbal, and global learning styles.

b. Multimedia
It is a source of supporting learning in the form of images or videos in the same context as the material studied by students. Multimedia has a predominantly sequential and applicative image, so the appropriate learning style is reflexive, sensitive, visual, and sequential.

c. Book

They are learning resources in the form of books or literature according to the content presented in order and context of students' material. Learning styles suitable for this supporting content have good analytical skills and are dominant in text media, so that appropriate are reflexive, intuitive, verbal, and sequential.

d. Mind Map

It is a learning resource presented in the form of an interconnected mind map. The mind map that is present is by the context of the material studied by students. The right learning style for supporting learning resources actively likes real and dominant things in visual media so that what is appropriate is active, intuitive, visual, and global.

The relationship between the form of learning content and learning styles can see in table 3

Table 3. learning Support Content

\begin{tabular}{|c|c|c|c|c|c|c|c|c|c|}
\hline & & \multicolumn{8}{|c|}{ Gaya Belajar FLSM } \\
\hline & & 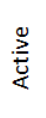 & 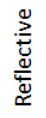 & $\begin{array}{l}\stackrel{\infty}{=} \\
\text { : } \\
\stackrel{w}{N} \\
\sim\end{array}$ & 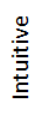 & $\begin{array}{l}\overline{00} \\
\overline{30} \\
\frac{05}{7}\end{array}$ & 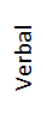 & 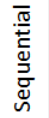 & $\begin{array}{l}\bar{\pi} \\
\text { 은 }\end{array}$ \\
\hline \multirow{4}{*}{ 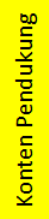 } & Web Ref & $\mathrm{x}$ & & $\mathrm{x}$ & & & $\mathrm{x}$ & & $\mathrm{x}$ \\
\hline & Multimedia & & $x$ & $x$ & & $x$ & & $x$ & \\
\hline & Book & & $x$ & & $x$ & & $x$ & $x$ & \\
\hline & Mind Map & $\mathrm{x}$ & & & $x$ & $x$ & & & $x$ \\
\hline
\end{tabular}

Implementation of the types of learning material content can see in figure 5 .

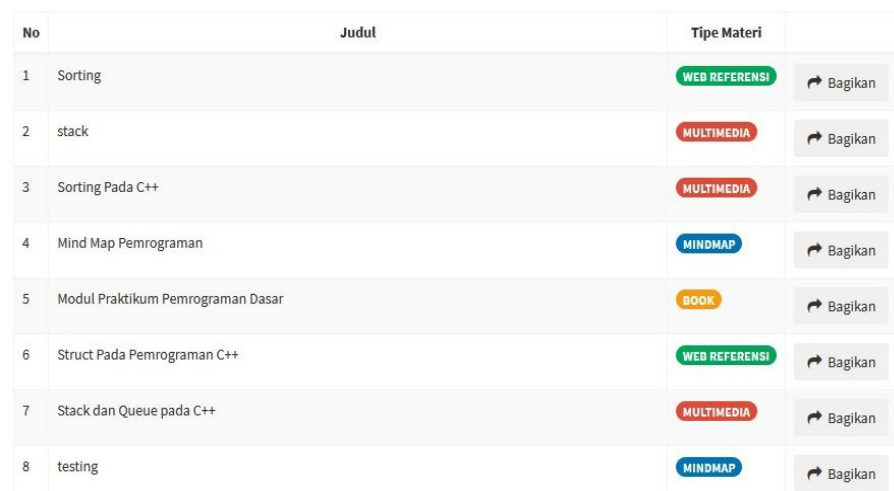

Figure 5: Material Management 


\subsection{Status of Material Requirements}

Teachers have an important role so that e-learning that is developing can be using correctly. The important thing that teachers need to do is make material and then share it with the class they teach. In making the material, the teacher demands that the material he makes is by students' needs. The features of the material needs are presenting. It is presenting in the classes they teach.

The status of material content needs can be important information for teachers because it displays the number of students based on material content that matches their learning style. With the need for material content, it hopes that it will become a reference for teachers preparing material based on their needs. The following is a picture of the detailed material requirements for a class.

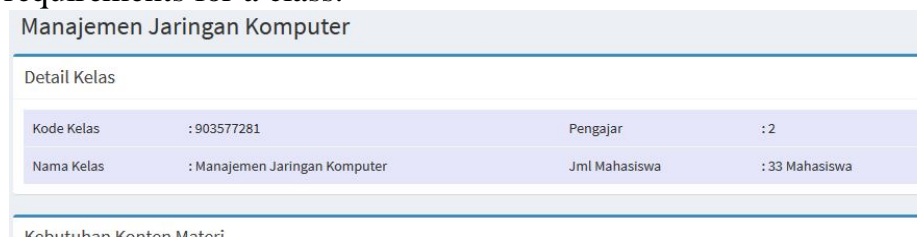

Kebutuhan Konten Materi

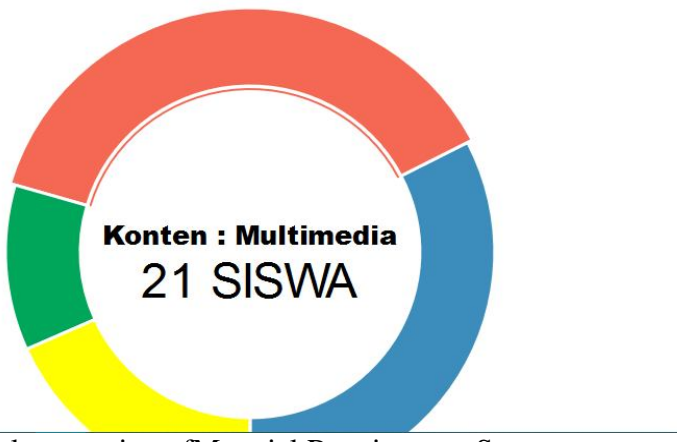

Figure 6: Implementation ofMaterial Requirement Status

After the lecturer makes the material according to the form of student learning content (according to the learning style), the lecturer distributes the material. The material obtained has also been filtered so that the material he gets will match his learning preferences. In the implementation of the system, it can see in Figure 7.

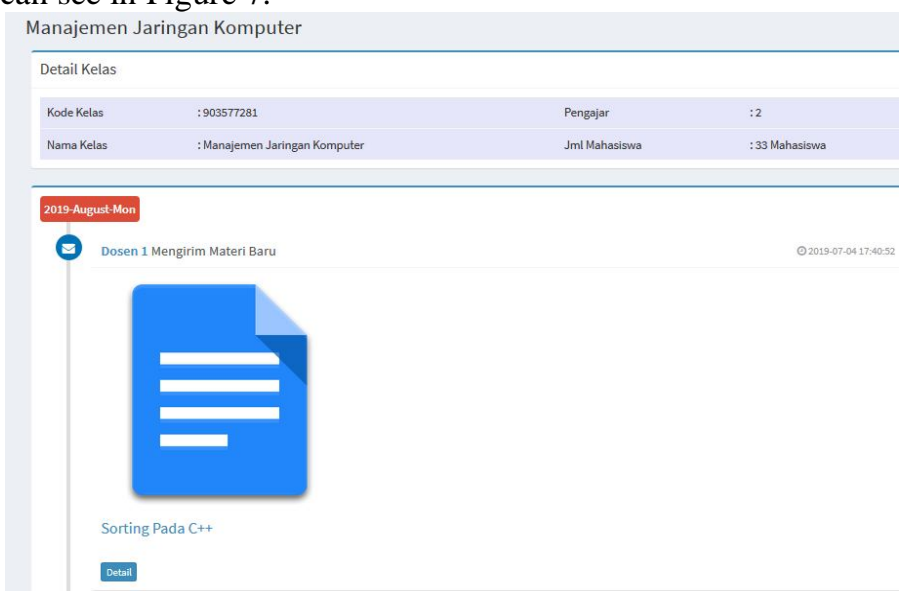

Figure 7: Student Material Status Page

\section{CONCLUSION}

Based on the discussions that carry out while developing adaptive e-learning, the authors obtained several conclusions, as follows conclusions that the author can describe:

1. Adaptive e-learning that is building to provide learning content according to user preferences for students to learn more effectively because it gets the learning material their preference.

2. With material content obtained by students according to their preferences can increase student interest in learning. Students can learn interest increased, assisted by a variety of materials.

3. Adaptive e-learning is expecting to build a learning system new in the world of education in the future. Provide models for learning that can improve the quality of education to be better.

\section{ACKNOWLEDGEMENT}

The preferred spelling of the word "acknowledgment" in American English is without an "e" after the "g." Use the singular heading even if they have many acknowledgments. Avoid expressions such as "One of us (S.B.A.) would like to thank ... ." Instead, write "F. A. Author thanks ... ." Sponsor and financial support acknowledgments place in the unnumbered footnote on the first page.

\section{REFERENCES}

1. Correia, Ana-Paula, Chenxi Liu, and Fan Xu. Evaluating videoconferencing systems for the quality of the educational experience,Distance Education, 1-24, 2020.

2. Segrave, Stephen, and Dale Holt. Contemporary learning environments: designing e-learning for education in the professions, Distance Education, 24.1, 7-24, 2003.

3. www.worldometers.info.COVID-19 Coronavirus Pandemic,https://www.worldometers.info/coronavirus/? ,accessed at 10 October 2020.

4. Dubey, Akash Dutt, and Shreya Tripathi. Analysing the sentiments towards work-from-home experience during covid-19 pandemic,Journal of Innovation Management 8.1, 2020.

5. Carvalho, Vitor Oliveira, and Caroline Oliveira Gois. COVID-19 pandemic and home-based physical activity,The Journal of Allergy and Clinical Immunology: In Practice, 8.8, 2833-2834, 2020.

6. Hung, Ruyu, and Unik Ambar Wati. Digital Home Schooling'During the Pandemic: Possibilities and Challenges,Knowledge Cultures 8.2, 36-43, 2020.

7. ReenaBhavyaet and Sambhav S.Role of Mobile Communication withEmerging Technology in COVID'19. International Journal of Advanced Trends in Computer Science and Engineering, 9(3), 3338-3344, May-June 2020.

8. Pertiwi, Aditya Putri, Puri, D., Pratama, Y. A., \& Wang, G. Analysis loyalty in video conference application zoom on covid 19 quarantine in Jakarta,International 
Journal of Advanced Trends in Computer Science and Engineering, 9.3,2020.

9. Mjhool, Ahmed Yaseen, Ahmed Hazim Alhilali, and Salam Al-Augby. A proposed architecture of big educational data using hadoop at the University of Kufa.International Journal of Electrical and Computer Engineering, 9.6,4970, 2019.

10. Hachmoud, S., Hachmoud, A., Meddaoui, A., \&Allali, H. Analysis of students online learning behavior in a pedagogical model combining blended learning and competency based approach.International Journal of Advanced Trends in Computer Science and Engineering, 8(6), 3389-3395,2019.

11. Chang, Yi-Hsingand Yen-Yi Chen. Yet another adaptive learning management system based on Felder and Silverman's e-learning styles and Mashup. Southern Taiwan University of Science and Technology,Taiwan.2015.

12. Suteja, Bernard

$\mathrm{R}$.

PersonalisasiKontenPendukungPembelajaran Online Berbasis Model Gaya BelajarFelder Silverman. Teknik InformatikaUK. MaranathaBandung.2016.

13. Bernard, Jason et al..Learning Style Identifier: Improving The precision of learning style identification through computational intelligence algorithms. School of Computing AndInformationSystems,AthabascaUniversity,12001001 1-109Street,Edmonton,ABT5J3S8,2017.

14. Surjono, Herman Dwiand Nurkhamid. Pengembangan Model E-learning AdaptifTerhadapKeragaman Gaya BelajarMahasiswaUntukMeningkatkanEfektivitasPem belajaran.Universitas Negeri Yogyakarta. 2008

15. Surjono, Herman Dwi. The Design of Adaptive E-Learning System based on Student's Learning Styles. Electronics Education Department, Yogyakarta State University Yogyakarta-Indonesia. 2011.

16. Supangatdan SadewaYudha,Ery..Determinationofinterfacedesignattr ibutesone-learning based on user personality characteristics, 1-8,10.1109/CAIPT.2017.8320676.2017.

17. Supangat, Supangat\&HaryatiChandar, Francisca \&Hermanto, Agus. The design of e- learning applications by considering aspects of the user's personality based on students take courses in human-computer interaction,MATEC Web of Conferences, 154 , 03009,10.1051/matecconf/201815403009, 2018.

18. Ziaurrahman, Ziaurrahman, and Herman Dwi Surjono. Pengembangan e-learning adaptif pada mata pelajaran Pendidikan Agama Islam untuk kelas X SMA, Jurnal Inovasi Teknologi Pendidikan, 4.2, 119-129, 2017.

19. ImelS.E-learning-trends and issues alert (report No-40), Washington, DC: Office of EducationalResearch and Improvement, 2002.

20. Marković, Suzana, and Nenad Jovanović. Learning style as a factor which affects the quality of e-learning,Artificial Intelligence Review, 38.4, 303-312, 2012.
21. Sadler-Smith E,Learning styles and instructional design,Innovations in education and training international, vol 33, 185-193, 1996.

22. Felder, Richard M., and Linda K. Silverman. Learning and teaching styles in engineering education,Engineering education, 78.7, 674-681, 1988. Alfaro, L., Rivera, C., Luna-Urquizo, J., Castaneda, E., \&Fialho, F. Utilization of a neuro fuzzy model for the online detection of learning styles in adaptive e-learning systems, International Journal of Advanced Computer Science and Applications, 9.12, 9-17, 2018. 